\title{
Pathogenic Interactions Between Xanthomonas axonopodis pv. citri and Cultivars of Pummelo (Citrus grandis)
}

\author{
H. Shiotani, K. Ozaki, and S. Tsuyumu
}

First and second authors: Department of Citriculture, National Institute of Fruit Tree Science, Kuchinotsu, Nagasaki 859-2501, Japan; and third author: Faculty of Agriculture, Shizuoka University, Shizuoka 422-8529, Japan.

Current address of K. Ozaki: Faculty of Horticulture, Minami Kyushu University, Takanabe, Miyazaki 884-0003, Japan.

Accepted for publication 23 August 2000.

\begin{abstract}
Shiotani, H., Ozaki, K., and Tsuyumu, S. 2000. Pathogenic interactions between Xanthomonas axonopodis pv. citri and cultivars of pummelo (Citrus grandis). Phytopathology 90:1383-1389.

The aggressiveness of strains of Xanthomonas axonopodis pv. citri on seven Citrus species, including Citrus sinensis (navel orange), C. paradisi (grapefruit), C. unshiu (Satsuma mandarin), C. junos (Yuzu), C. aurantifolia ('Mexican' lime), C. tachibana (Tachibana), and C. grandis (pummelo: 'Otachibana', 'Banpeiyu', and 'Anseikan'), were assessed by comparing lesion expansion and growth in planta, using a prick inoculation method. The existence of two groups distinct in aggressiveness was demonstrated on the pummelo cultivars, whereas the remaining species

tinct in lesion expansion and growth in planta; however, both caused canker lesions on the 'Otachibana' pummelo. The sensitivity of the bacterial strains to phages $\mathrm{Cp} 1$ and $\mathrm{Cp} 2$ was associated with differences in aggressiveness. Namely, all the strains sensitive to $\mathrm{Cp} 2$ but resistant to Cp1 were aggressive to 'Otachibana', whereas all the strains sensitive to $\mathrm{Cp} 1$ but resistant to $\mathrm{Cp} 2$ were weakly aggressive. When a repetitive sequence-based polymerase chain reaction amplification was carried out by enterobacterial repetitive intergeneric consensus (ERIC) sequences (ERIC1R and ERIC2) as the primers, these two groups were also distinguishable by the presence or absence of a 1.8-kb DNA fragment among otherwise identical fragments. The $1.8-\mathrm{kb}$ fragment was amplified only from the strains aggressive to $C$. grandis.
\end{abstract} tested were uniformly susceptible. The two groups of strains were dis-
Asiatic citrus canker, which is caused by Xanthomonas axonopodis pv. citri (synonym X. campestris pv. citri pathotype A) (27), is one of the biggest problems in citrus production worldwide (23). X. axonopodis pv. citri has a broad host range among members of the Rutaceae, although differences in susceptibility exist among Citrus spp. (22). Little is known, however, about differences in pathogenicity, including aggressiveness within this pathovar. Several restriction fragment length polymorphism (RFLP) analyses for $X$. axonopodis pv. citri have indicated that, with few exceptions, these bacteria share a similar genetic background $(5,9,23)$. This genetic uniformity seems to explain the uniformity of their aggressiveness on different host species of the Rutaceae (23).

Recently, strains of $X$. axonopodis pv. citri have been isolated from 'Mexican' lime (Citrus aurantifolia Swingle) trees in Southwest Asia that are phenotypically distinct from other strains of this pathovar (28). The Southwest Asian strains elicited typical canker lesions on 'Mexican' lime but not on other Citrus spp., such as grapefruit ( $C$. paradisi Macf.) (28). DNA analyses could not distinguish the Southwest Asian strains from other strains of $X$. axonopodis pv. citri (28). However, the Southwest Asian strains were distinct, because they had no affinity for polyclonal antiserum prepared against a typical strain of $X$. axonopodis pv. citri (28).

Several studies have reported distinct phenotypes among Japanese strains of $X$. axonopodis pv. citri $(6,7,30)$. They differ in sensitivity to the bacterial phages $\mathrm{Cp} 1$ and $\mathrm{Cp} 2$ (17), and only strains sensitive to $\mathrm{Cp} 1$ are able to oxidize mannitol $(6,30)$. Japanese strains of $X$. axonopodis pv. citri resemble typical strains of $X$. axonopodis pv. citri because of their affinity to a polyclonal antiserum prepared against the pathogen and because of the typical

Corresponding author: H. Shiotani; E-mail address: hiroshi@kcnt.affrc.go.jp

Publication no. P-2000-1002-01R

(C) 2000 The American Phytopathological Society canker symptoms they produce on Citrus spp. (7). Because Japanese strains have been identified as $X$. axonopodis pv. citri, it would be reasonable to expect to find no differences in aggressiveness among the strains. The Citrus spp. used for pathogenicity tests in previous studies, however, were restricted to the main species planted in Japan. In order to breed resistant cultivars and eventually control this disease, we should investigate differences in pathogenicity among the strains by testing them against a wider variety of species.

In this paper, we describe differential aggressiveness among Japanese strains of $X$. axonopodis pv. citri on pummelo (C. grandis Osbeck) cultivars; in addition, we discuss a specific DNA fragment found in aggressive strains amplified with repetitive sequence-based polymerase chain reaction (rep-PCR), a method that has been developed to examine relationships among bacterial species, including the xanthomonads $(16,26)$. A possible relationship between differential aggressiveness and phage sensitivity among $X$. axonopodis pv. citri strains is also discussed.

\section{MATERIALS AND METHODS}

Bacterial strains. Strains of $X$. axonopodis pv. citri were isolated from lesions on the leaves of 10 Citrus spp. and 6 hybrids from 27 groves at different locations in Japan (Table 1). They were serologically identified as $X$. axonopodis pv. citri by an agglutination test, using a rabbit antiserum prepared by previously described methods (19), namely, by injecting a heat-treated cell suspension of bacterial strain 9011 of $X$. axonopodis pv. citri. After identification, cultures of the strains were suspended in a skim milk medium (10\% skim milk and $1 \%$ sodium L-glutamate) and maintained at $-80^{\circ} \mathrm{C}$. Strains $\mathrm{KC} 5, \mathrm{KC} 11, \mathrm{KC} 12, \mathrm{KC} 16, \mathrm{KC} 19$, $\mathrm{KC} 21$, and $\mathrm{KC} 34$ were randomly selected and used in pathogenicity tests with seven Citrus spp. (described below) to find those species on which differences in aggressiveness could be observed. The reference strains were NCPPB409 of X. axonopodis 
pv. citri and XC148 of X. axonopodis pv. aurantifolii (27) (synonym $X$. campestris pv. aurantifolli), which is causal agent of citrus cancrosis B (23).

Plant materials. In this study, seven Citrus spp. were used: $C$. sinensis Osbeck (navel orange), C. paradisi (grapefruit), C. unshiu Marc. (Satsuma mandarin), C. aurantifolia ('Mexican' lime), $C$. junos Sieb. ex Tanaka (Yuzu), C. tachibana Tanaka (Tachibana), and $C$. grandis (pummelo 'Otachibana', 'Banpeiyu', and 'Anseikan'). Scions of these had been grafted onto potted 2-yearold rootstocks of $C$. jambhiri Lush (Rough lemon).

Differences in lesion expansion. The aggressiveness of each strain of $X$. axonopodis pv. citri was evaluated after inoculation into leaves of different Citrus spp. $(7,8,15)$. Bacterial strains were grown on Wakimoto's potato semisynthetic medium with $1.5 \%$ agar (PSA medium) (30) at $28^{\circ} \mathrm{C}$ for 1 day. Bacteria were suspended in $0.85 \% \mathrm{NaCl}$ at a concentration of $1 \times 10^{8}$ cells per $\mathrm{ml}$, and approximately $3 \mu$ of the suspension was placed in each of six spots on an attached mature leaf of each citrus plant. Immediately after pricking the leaves through the suspension with an insect pin (0.5-mm diameter), the inoculum drops were wiped off with sterile cotton. Four leaves of each citrus plant were used for each strain, and the assays were repeated three times. The results of one test are reported. The inoculated plants were grown in a greenhouse in which the temperature was $28^{\circ} \mathrm{C}$ during the day and $25^{\circ} \mathrm{C}$ at night. The diameters of the circular lesions, including cork tissue and water-soaked margin, were measured 40 days after inoculation. Differences in lesion expansion among strains for each host were evaluated by analysis of the Tukey-Kramer honestly significant difference (HSD) test.

Bacterial growth in planta. The growth in planta of an aggressive and a weakly aggressive strain of $X$. axonopodis pv. citri were observed. An aggressive strain, KC16, and a weakly aggres-

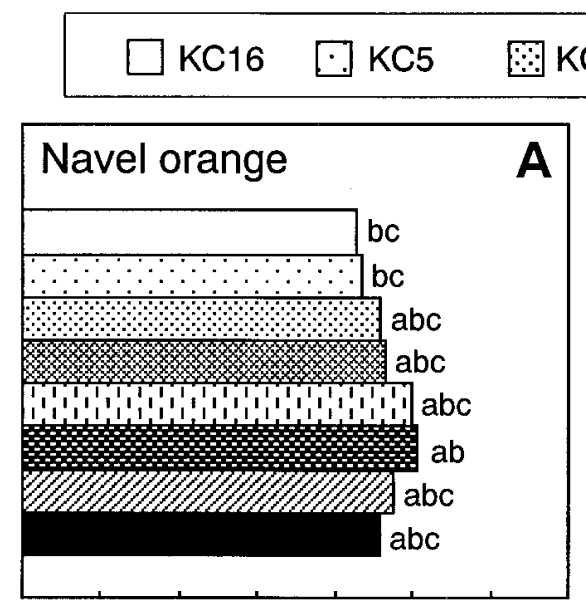

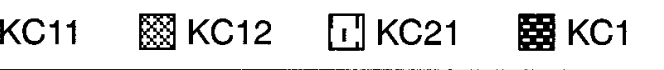

Ø KC19

KC34
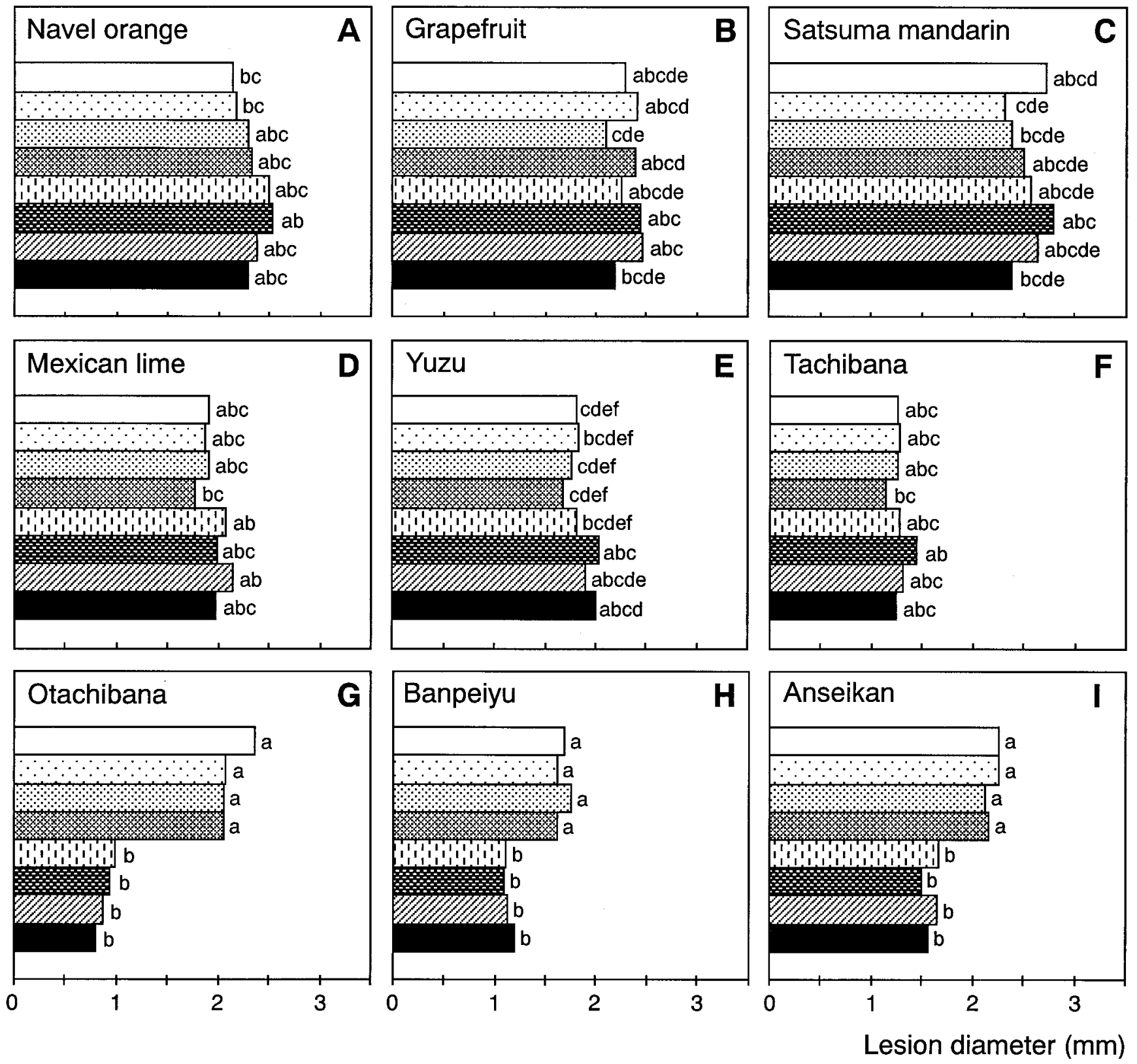

Fig. 1. Lesion expansion for eight strains of Xanthomonas axonopodis pv. citri on citrus species, A, navel orange; B, grapefruit; C, Satsuma mandarin; D, 'Mexican' lime; E, Yuzu; F, Tachibana; G, 'Otachibana'; H, 'Banpeiyu'; and I, 'Anseikan'. Each bar represents the mean diameter of 24 lesions from each strain 40 days after inoculation by pricking the attached leaves of each species. Bars with different letters differ significantly at $\alpha=0.01$ according to the TukeyKramer honestly significant difference test. 
sive strain, KC19, were randomly selected for use in the experiment. Strain XC148 of X. axonopodis pv. aurantifolli was used for comparison. The bacteria suspended in $0.85 \% \mathrm{NaCl}$ were inoculated into mature attached leaves of $C$. grandis ('Otachibana') and $C$. sinensis (navel orange) by pricking as described above or by infiltrating with a syringe at a concentration of $1 \times 10^{5}$ cells per $\mathrm{ml}$. The inoculated plants were grown in a greenhouse in which the temperature was controlled as described above. The bacterial populations in the lesions at $0,1,2,3,4,8$, and 16 days after inoculation were determined by removing the lesion with a corkborer. Internal populations of leaves inoculated by infiltrating
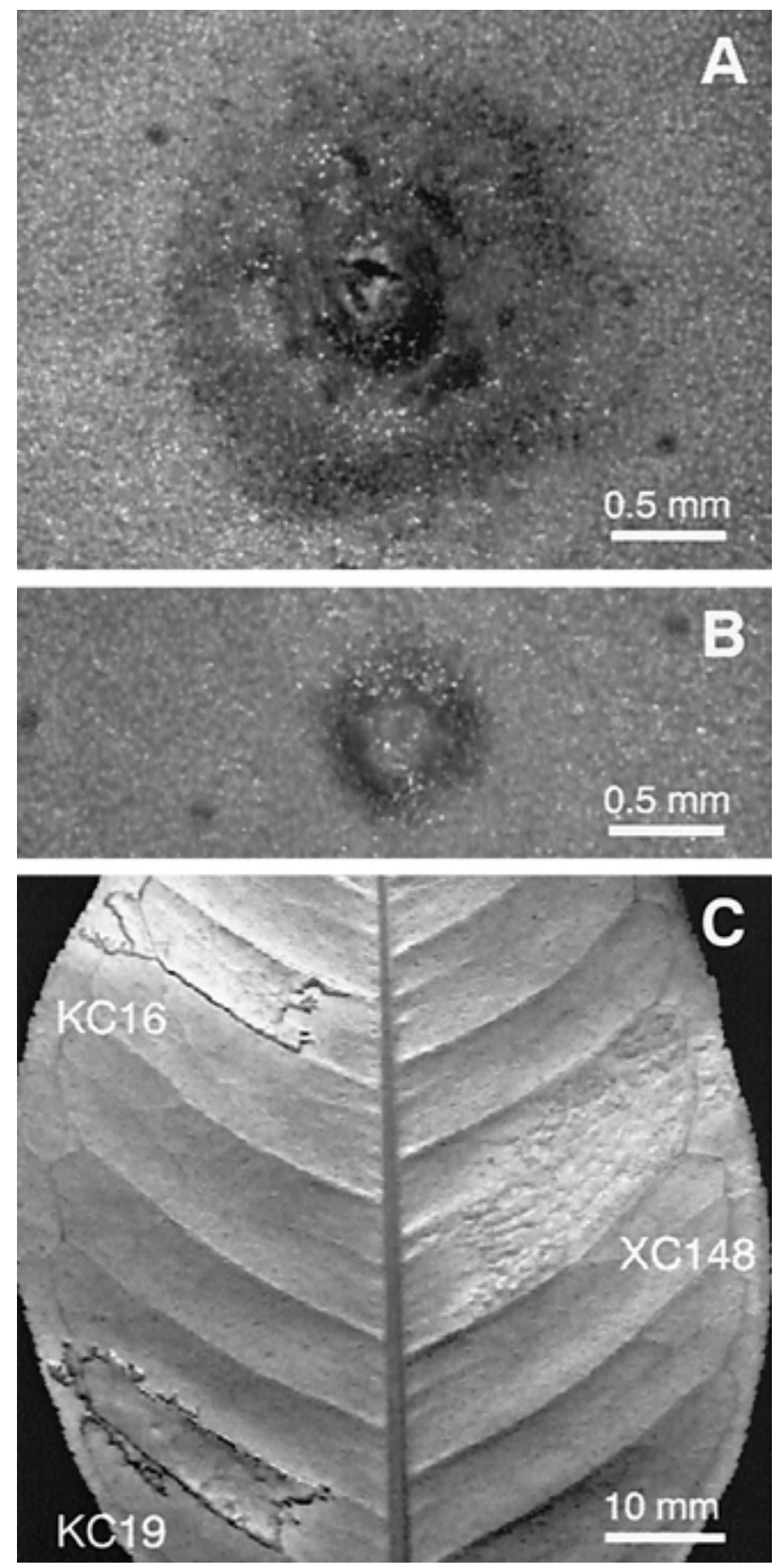

Fig. 2. Lesions on attached mature leaves of pummelo 'Otachibana' inoculated with strains $\mathrm{KC} 16$ and $\mathrm{KC} 19$ of Xanthomonas axonopodis pv. citri and strain XC148 of X. axonopodis pv. aurantifolli. A and B, Lesions developed 40 days after inoculation by pin-pricking with $\mathbf{A}$, the aggressive strain $\mathrm{KC} 16$ and $\mathbf{B}$, the weakly aggressive strain KC19. Strain KC16 caused more extensive corked tissue and a larger water-soaked margin than KC19. C, Lesions photographed 10 days after inoculation by infiltration with bacterial suspensions of the indicated strains (KC16, KC19, and XC148). All the strains elicited canker symptoms 5 days after inoculation of the cultivar. were determined at $0,5,10,15$, and 20 days after inoculation by harvesting a leaf disk $\left(0.52 \mathrm{~cm}^{2}\right)$ from a randomly chosen site. The removed tissue was macerated in $0.85 \% \mathrm{NaCl}$, and the suspension was plated on a semiselective XCSM medium (18) composed of $1 \%$ starch, $0.2 \%$ polypeptone, $0.1 \%$ monopotassium phosphate, $0.02 \%$ magnesium chloride, $0.05 \%$ calcium nitrate, $0.1 \%$ disodium hydrogenphosphate dibasic, and $1.5 \%$ agar in distilled water. After autoclaving, methylgreen, cyclohexmide, chloramphenicol, and fradiomycin sulfate were added to final concentrations of 10 , 100,1 , and $1 \mu \mathrm{g} / \mathrm{ml}$, respectively.

Symptoms elicited by $X$. axonopodis pv. citri strains in $C$. grandis. Cultures of $\mathrm{KC} 16$ and $\mathrm{KC} 19$ strains grown on PSA medium were suspended in $0.85 \% \mathrm{NaCl}$ at a concentration of $1 \times$ $10^{8}$ cells per ml. A syringe was used to inject a bacterial suspension of each strain into the intercellular spaces of mature and immature attached leaves of $C$. grandis 'Otachibana'. Reference strain XC148 of $X$. axonopodis pv. aurantifolli also was used in this experiment.

Phage sensitivity. Phages $\mathrm{Cp} 1$ and $\mathrm{Cp} 2$ were provided by the Moji Plant Protection Station, Fukuoka, Japan. The drop method described by Wakimoto (30) was used for the phage test. The bacterial strains were grown on PSA medium at $28^{\circ} \mathrm{C}$ for 1 day and were suspended in sterile distilled water at a concentration of $1 \times 10^{8}$ cells per $\mathrm{ml}$. A mixture of $2 \mathrm{ml}$ of the bacterial suspension and $5 \mathrm{ml}$ of PSA medium that was melted and kept at $55^{\circ} \mathrm{C}$, was plated. Each phage suspension at a titer of $1 \times 10^{9}$ plaque forming units per ml was spotted on the medium, and the plates were incubated at $28^{\circ} \mathrm{C}$ for $15 \mathrm{~h}$. A zone of clearing or plaques indicated sensitivity to the phage.

Extraction of genomic DNA. A modified procedure described by Ausubel et al. (1) was used to extract total genomic DNA. Bacteria were grown in $2 \mathrm{ml}$ of YP medium $(0.3 \%$ yeast extract

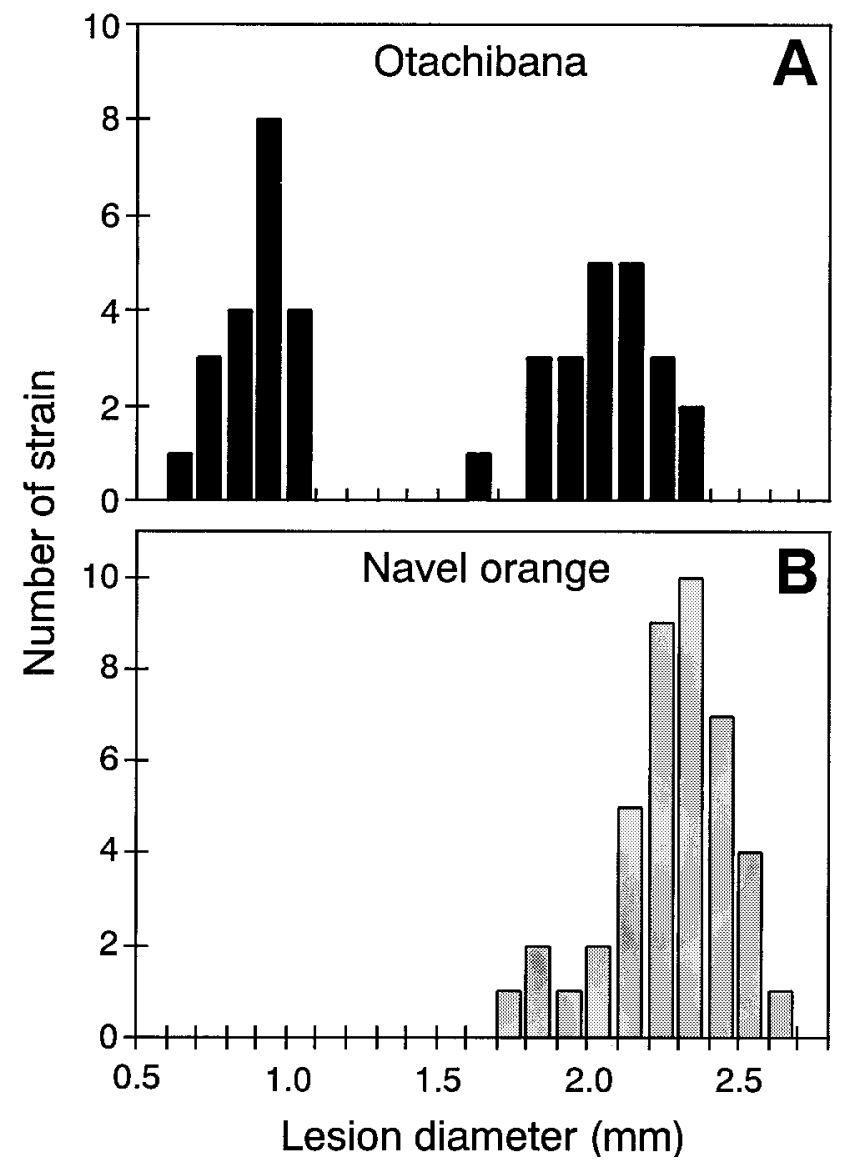

Fig. 3. Distribution of Xanthomonas axonopodis pv. citri strains by lesion size on attached leaves of $\mathbf{A}$, pummelo $\mathrm{cv}$. Otachibana and $\mathbf{B}$, navel orange 40 days after inoculation by pin-pricking. The 42 strains shown are listed in Table 1. 
and $0.5 \%$ polypeptone) in $15-\mathrm{ml}$ test tubes at $28^{\circ} \mathrm{C}$ for $20 \mathrm{~h}$ on a shaker $(150 \mathrm{rpm})$. Bacterial cells were washed twice with $2 \mathrm{M}$ $\mathrm{NaCl}$ and suspended in $600 \mu \mathrm{l}$ of Tris-EDTA (TE) buffer ( $\mathrm{pH} 8.0)$ (21) containing sodium dodecyl sulfate (SDS) and proteinase $\mathrm{K}$ at a final concentration of $2 \%$ and $250 \mu \mathrm{g} / \mathrm{ml}$, respectively. After incubation at $37^{\circ} \mathrm{C}$ for $1 \mathrm{~h}, 100 \mu \mathrm{l}$ of $5 \mathrm{M} \mathrm{NaCl}$ was added to the solution, which was mixed thoroughly. Eighty microliters of cetyltrimethylammoniumbromide (CTAB)- $\mathrm{NaCl}$ solution $(10 \%$ hexadecyltrimethyl ammonium bromide in $0.7 \mathrm{M} \mathrm{NaCl}$ ) was added to the solution, which was mixed thoroughly and incubated at $65^{\circ} \mathrm{C}$ for $10 \mathrm{~min}$. DNA was extracted using chloroform isoamyl alcohol (24:1) and phenol chloroform isoamyl alcohol (25:24:1) precipitated by the addition of $0.6 \mathrm{vol}$ of isopropanol, and washed with $70 \%$ ethanol. Pelleted DNA was dried in a vacuum and dissolved in $100 \mu \mathrm{l}$ of TE buffer ( $\mathrm{pH}$ 8.0).

Oligonucleotide primers and polymerase chain reaction condition. The reaction mixture and amplification conditions for the repetitive sequence-based polymerase chain reaction (repPCR) were those described by Louws et al. (16). The primers enterobacterial repetitive intergeneric consensus (ERIC) $1 \mathrm{R}$ [5'ATGTAAGCTCCTGGGGATTCAA-3'] and ERIC2 [5'-AAGTAAGTGACTGGGGTGAGCG-3'] (16) were purchased from Sawady Technology, Tokyo, Japan. Each 25- $\mu$ l PCR reaction buffer contained $50 \mathrm{pmol}$ of each primer, $50 \mathrm{ng}$ of template total DNA, $1.25 \mathrm{mM}$ each of four dNTPs, 2 units AmpliTaq polymerase (Perkin-Elmer/Cetus, Foster City, CA), and 10\% dimethyl sulfoxide (DMSO) (vol/vol) (14). The PCR amplification was carried out by a DNA thermal cycler (Model 480, Perkin-Elmer/Cetus). The PCR mixture was overlaid with $25 \mu$ of mineral oil during amplification. The initial denaturation was at $95^{\circ} \mathrm{C}$ for $7 \mathrm{~min}$, followed by 30 cycles of denaturation at $94^{\circ} \mathrm{C}$ for $1 \mathrm{~min}$, annealing at $52^{\circ} \mathrm{C}$ for $1 \mathrm{~min}$, and extension at $65^{\circ} \mathrm{C}$ for $8 \mathrm{~min}$, with a final extension at $65^{\circ} \mathrm{C}$ for $15 \mathrm{~min}$ and a soak at $4^{\circ} \mathrm{C}(16)$.

An $8-\mu$ portion of the amplified PCR product was subjected to electrophoresis at $4^{\circ} \mathrm{C}$ on a $1.5 \%$ agarose gel in $1 \times$ Tris-acetateEDTA (TAE) buffer (21) for $3 \mathrm{~h}$ at $100 \mathrm{~V}$, stained with ethidium bromide, and photographed on a UV transilluminator with Polaroid film (Type 667, Polaroid Corp., Cambridge, MA).

TABLE 1. Strains of Xanthomonas spp. used in this study

\begin{tabular}{|c|c|c|c|c|c|}
\hline \multirow[b]{2}{*}{ Strain } & \multirow[b]{2}{*}{ Host plant } & \multirow[b]{2}{*}{ Origin $^{\mathrm{a}}$} & \multirow[b]{2}{*}{ Aggressiveness $^{\mathrm{b}}$} & \multicolumn{2}{|c|}{ Phage sensitivity $^{\mathrm{c}}$} \\
\hline & & & & Cp1 & $\mathrm{Cp} 2$ \\
\hline \multicolumn{6}{|c|}{ X. axonopodis pv. citri } \\
\hline NCPPB $409^{\mathrm{d}}$ & Citrus limon & New Zealand & ++ & $\mathrm{S}$ & $\mathrm{S}$ \\
\hline 9011 & C. unshiu & Matsubase, Kumamoto & ++ & $\mathrm{R}$ & $\mathrm{S}$ \\
\hline $\mathrm{KC} 2$ & C. grandis & Matsubase, Kumamoto & ++ & $\mathrm{S}$ & $\mathrm{S}$ \\
\hline $\mathrm{KC} 4$ & C. limon & Matsubase, Kumamoto & ++ & $\mathrm{R}$ & $\mathrm{S}$ \\
\hline KC5 & C. hassaku & Gamagori, Aichi & ++ & $\mathrm{R}$ & $\mathrm{S}$ \\
\hline KC6 & C. jambihili & Gamagori, Aichi & ++ & $\mathrm{R}$ & $\mathrm{S}$ \\
\hline $\mathrm{KC} 10$ & C. tamurana & Takaono, Kagoshima & ++ & $\mathrm{R}$ & $\mathrm{S}$ \\
\hline $\mathrm{KC} 11$ & (C. nobilis $\times$ C. unshiu $) \times C$. reticulata & Nago, Okinawa & ++ & $\mathrm{R}$ & $\mathrm{S}$ \\
\hline $\mathrm{KC} 12$ & C. reticulata $\times$ C. sinensis & Nago, Okinawa & ++ & $\mathrm{R}$ & $\mathrm{R}$ \\
\hline $\mathrm{KC} 13$ & $C$. sinensis $\times C$. clementina & Nago, Okinawa & ++ & $\mathrm{R}$ & $\mathrm{S}$ \\
\hline $\mathrm{KC} 15$ & $(C$. nobilis $\times C$. unshiu $) \times C$. reticulata & Kochi, Kochi & ++ & $\mathrm{R}$ & $\mathrm{S}$ \\
\hline $\mathrm{KC} 16$ & C. natsudaidai & Tarumizu, Kagoshima & ++ & $\mathrm{R}$ & $\mathrm{S}$ \\
\hline $\mathrm{KC} 17$ & C. unshiu & Shima, Fukuoka & ++ & $\mathrm{R}$ & $\mathrm{S}$ \\
\hline KC18 & C. unshiu & Chita, Aichi & ++ & $\mathrm{R}$ & $\mathrm{S}$ \\
\hline $\mathrm{KC} 20$ & C. natsudaidai & Inami, Wakayana & ++ & $\mathrm{S}$ & $\mathrm{S}$ \\
\hline $\mathrm{KC} 22$ & C. tangerina $\times C$. grandis & Hirokawa, Wakayama & ++ & $\mathrm{R}$ & $\mathrm{S}$ \\
\hline $\mathrm{KC} 24$ & $C$. sinensis $\times C$. clementina & Nago, Okinawa & ++ & $\mathrm{R}$ & $\mathrm{S}$ \\
\hline $\mathrm{KC} 25$ & C. unshiu & Nago, Okinawa & ++ & $\mathrm{R}$ & $\mathrm{S}$ \\
\hline KC31 & C. unshiu & Minamata, Kumamoto & ++ & $\mathrm{R}$ & $\mathrm{S}$ \\
\hline KC36 & C. iyo & Ikata, Ehime & ++ & $\mathrm{R}$ & $\mathrm{S}$ \\
\hline KC37 & C. unshiu & Kashima, Saga & ++ & $\mathrm{R}$ & $\mathrm{S}$ \\
\hline KC38 & C. limon & Akune, Kagoshima & ++ & $\mathrm{R}$ & $\mathrm{S}$ \\
\hline $\mathrm{KC} 1$ & C. grandis & Matsubase, Kumamoto & + & $\mathrm{S}$ & $\mathrm{R}$ \\
\hline $\mathrm{KC} 3$ & $(C$. sinensis $\times$ C. unshiu $) \times C$. reticulata & Matsubase, Kumamoto & + & $\mathrm{S}$ & $\mathrm{S}$ \\
\hline $\mathrm{KC} 7$ & C. unshiu & Gamagori, Aichi & + & $\mathrm{S}$ & $\mathrm{R}$ \\
\hline $\mathrm{KC} 8$ & C. shaerocarpa & Tsukumi, Oita & + & $\mathrm{S}$ & $\mathrm{R}$ \\
\hline KC9 & C. sinensis & Tarumizu, Kagoshima & + & $\mathrm{S}$ & $\mathrm{R}$ \\
\hline $\mathrm{KC} 14$ & C. unshiu & Odawara, Kanagawa & + & $\mathrm{S}$ & $\mathrm{R}$ \\
\hline KC19 & C. unshiu & Tanabe, Wakayama & + & $\mathrm{S}$ & $\mathrm{R}$ \\
\hline $\mathrm{KC} 21$ & C. natsudaidai & Tanabe, Wakayama & + & $\mathrm{S}$ & $\mathrm{R}$ \\
\hline $\mathrm{KC} 23$ & C. limon & Yoshida, Ehime & + & $\mathrm{S}$ & $\mathrm{R}$ \\
\hline $\mathrm{KC} 26$ & C. unshiu & Koga, Fukuoka & + & $\mathrm{S}$ & $\mathrm{R}$ \\
\hline $\mathrm{KC} 27$ & C. sinensis & Shingu, Fukuoka & + & $\mathrm{S}$ & $\mathrm{R}$ \\
\hline $\mathrm{KC} 28$ & C. sinensis & Matsuyama, Ehime & + & $\mathrm{S}$ & $\mathrm{R}$ \\
\hline $\mathrm{KC} 29$ & C. iyo & Tobe, Ehime & + & $\mathrm{S}$ & $\mathrm{R}$ \\
\hline KC30 & C. sinensis & Yuasa, Wakayama & + & $\mathrm{S}$ & $\mathrm{R}$ \\
\hline $\mathrm{KC} 32$ & C. sinensis & Hondo, Kumamoto & + & $\mathrm{S}$ & $\mathrm{R}$ \\
\hline KC33 & C. iyo & Ikata, Ehime & + & $\mathrm{S}$ & $\mathrm{S}$ \\
\hline KC34 & C. natsudaidai & Seto, Ehime & + & $\mathrm{S}$ & $\mathrm{S}$ \\
\hline KC35 & C. unshiu & Yamamoto, Kagawa & + & $\mathrm{S}$ & $\mathrm{R}$ \\
\hline KC39 & (C. sinensis $\times$ C. unshiu $) \times C$. reticulata & Nichinan, Miyazaki & + & $\mathrm{S}$ & $\mathrm{R}$ \\
\hline $\mathrm{KC} 40$ & C. sinensis & Tobe, Ehime & + & $\mathrm{S}$ & $\mathrm{R}$ \\
\hline \multicolumn{6}{|c|}{$X$. axonopodis pv. aurantifolli } \\
\hline $\mathrm{XC} 148^{\mathrm{e}}$ & C. limon & Argentina & + & $\mathrm{R}$ & $\mathrm{R}$ \\
\hline
\end{tabular}

a Except for NCPPB409 and XC148 all strains originated in Japan.

b Aggressiveness in pathogenicity of each strain to C. grandis (cv. Otachibana); ++ = aggressive, $+=$ weakly aggressive.

c Sensitivity to phages $\mathrm{Cp} 1$ and $\mathrm{Cp} 2 ; \mathrm{S}=$ sensitive, $\mathrm{R}=$ resistant.

d National Collection of Plant Pathogenic Bacteria, England.

e The strain provided by J. S. Hartung. 


\section{RESULTS}

Distinct lesion expansion of $X$. axonopodis pv. citri strains on pummelo cultivars. To find Citrus spp. on which differences in aggressiveness of $X$. axonopodis pv. citri strains could be observed, eight strains of the pathogen were randomly selected and inoculated into attached mature leaves of seven Citrus spp. All strains caused water-soaked lesions at the inoculation sites within 5 days. On $C$. sinensis (navel orange), $C$. paradisi (grapefruit), $C$. unshiu (Satsuma mandarin), C. aurantifolia ('Mexican' lime), $C$. junos (Yuzu), and $C$. tachibana (Tachibana), no differences in lesion expansion among the bacterial strains were detected (Fig. 1A through F). However, different lesion expansion among the strains was observed on $C$. grandis cvs. (pummelos) Otachibana, Banpeiyu, and Anseikan. In particular, strains KC16, KC5, KC11, and $\mathrm{KC} 12$ uniformly produced larger lesions on the cultivars than $\mathrm{KC} 21, \mathrm{KC} 1, \mathrm{KC} 19$, and KC34 (Figs. 1G through I, 2A and B).

Testing an additional 32 strains of $X$. axonopodis pv. citri clearly demonstrated that at least two pathogenic (aggressive and weakly aggressive) groups infect 'Otachibana'. Namely, on 'Otachibana', the distribution of the lesions according to size was divided into two groups in contrast to a normal distribution of lesions observed on navel orange (Fig. 3A and B, Table 1).

In planta growth curves. In $C$. grandis 'Otachibana', populations of strains KC16 and KC19 increased similarly for the first 2 days after inoculation by pricking to approximately $1.5 \times 10^{5} \mathrm{CFU}$ per lesion (Fig. 4A). After 2 days, however, the rates of multiplication differed. After 8 days, populations of both strains fell, although the KC19 numbers decreased more rapidly than those of KC16 (Fig. 4A). Differences in growth in 'Otachibana' between $\mathrm{KC} 16$ and $\mathrm{KC} 19$ were also confirmed after inoculation by infil-

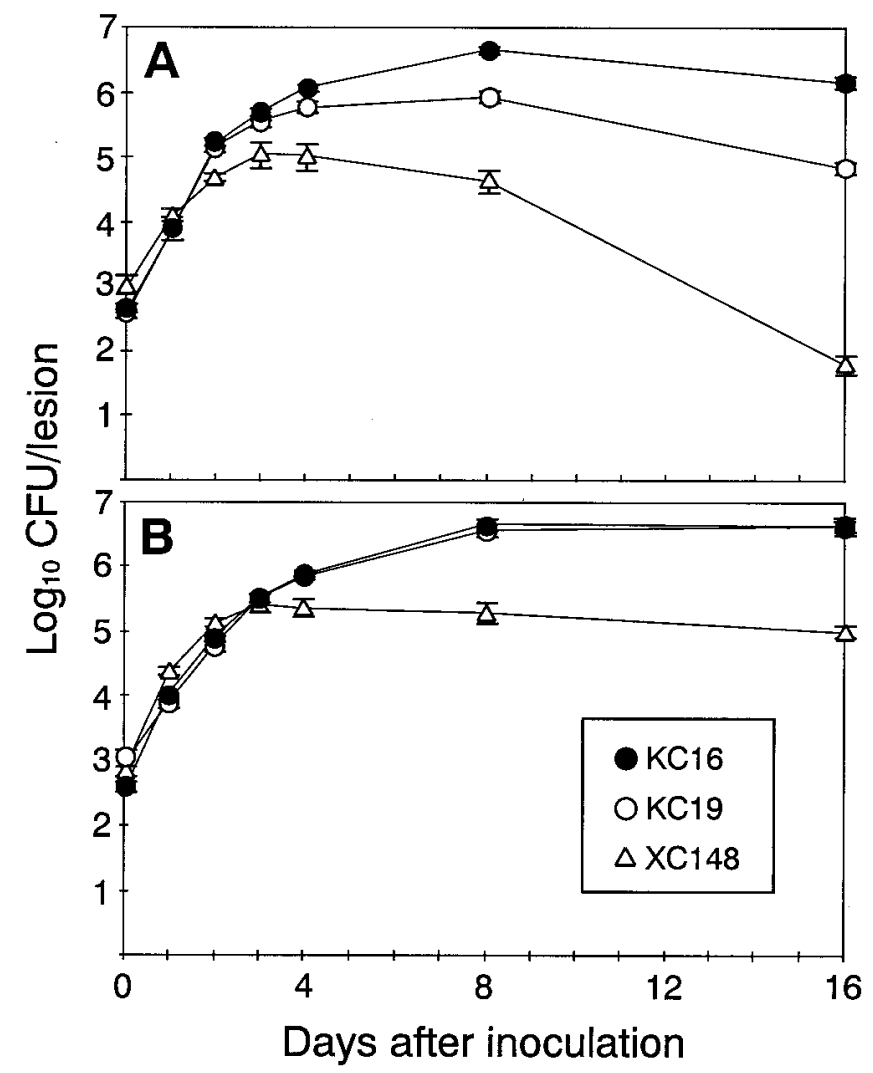

Fig. 4. Time course of bacterial growth in the leaves of citrus species $\mathbf{A}$, pummelo 'Otachibana' and B, navel orange. An aggressive strain of Xanthomonas axonopodis pv. citri (KC16), a weakly aggressive strain (KC19) and $X$. axonopodis pv. aurantifolli strain $\mathrm{XC148}$ were inoculated by pricking. Leaves were sampled for 16 days after inoculation. Values are means from three repetitions, and vertical bars represent the standard error at each sampling time. tration (Fig. 5A). Populations of both strains continued to increase beyond 10 days after inoculation, in contrast to a decrease in the population on plants treated with inoculation by pricking (Fig. 4A). In navel orange (C. sinensis), populations of the two strains inoculated by pricking and infiltrating were equivalent throughout the experiment (Figs. 4B and 5B).

Reference strain XC148 of X. axonopodis pv. aurantifolli increased in both 'Otachibana' and navel orange until 3 days after inoculation by pricking (Fig. 4A and B). After 3 days, however, the population of this strain increased only slightly in both host (Fig. 4A and B). When the strain was inoculated by infiltrating, no bacterial cells were obtained from the inoculated leaves of either host beyond 5 days after inoculation (Fig. 5A and B).

Symptoms elicited after infiltration of bacterial suspension. An aggressive and a weakly aggressive strain were infiltrated at high cell densities into 'Otachibana' to compare canker symptom development. Three days after inoculation, both strains KC16 and KC19 elicited water-soaking on a mature attached leaf of 'Otachibana'. An erumpent tissue reaction was observed 4 days after infiltration, not only with the suspension of strain $\mathrm{KC} 16$ but also with that of KC19 (Fig. 2C). Strain XC148 of X. axonopodis pv. aurantifolli was infiltrated into a mature leaf of 'Otachibana' and also elicited water-soaking and an erumpent tissue reaction 5 days after inoculation (Fig. 2C). The inoculation test with immature leaves from the plant showed the same results as those observed when mature leaves were used for all the strains tested (data not shown).

Phage sensitivity. All $X$. axonopodis pv. citri strains tested, except for strain $\mathrm{KC} 12$, were sensitive to the $\mathrm{Cp} 1$ or $\mathrm{Cp} 2$ phages (Table 1). Interestingly, all strains sensitive to $\mathrm{Cp} 1$ and resistant to Cp2 showed weak aggressiveness on 'Otachibana'. All strains

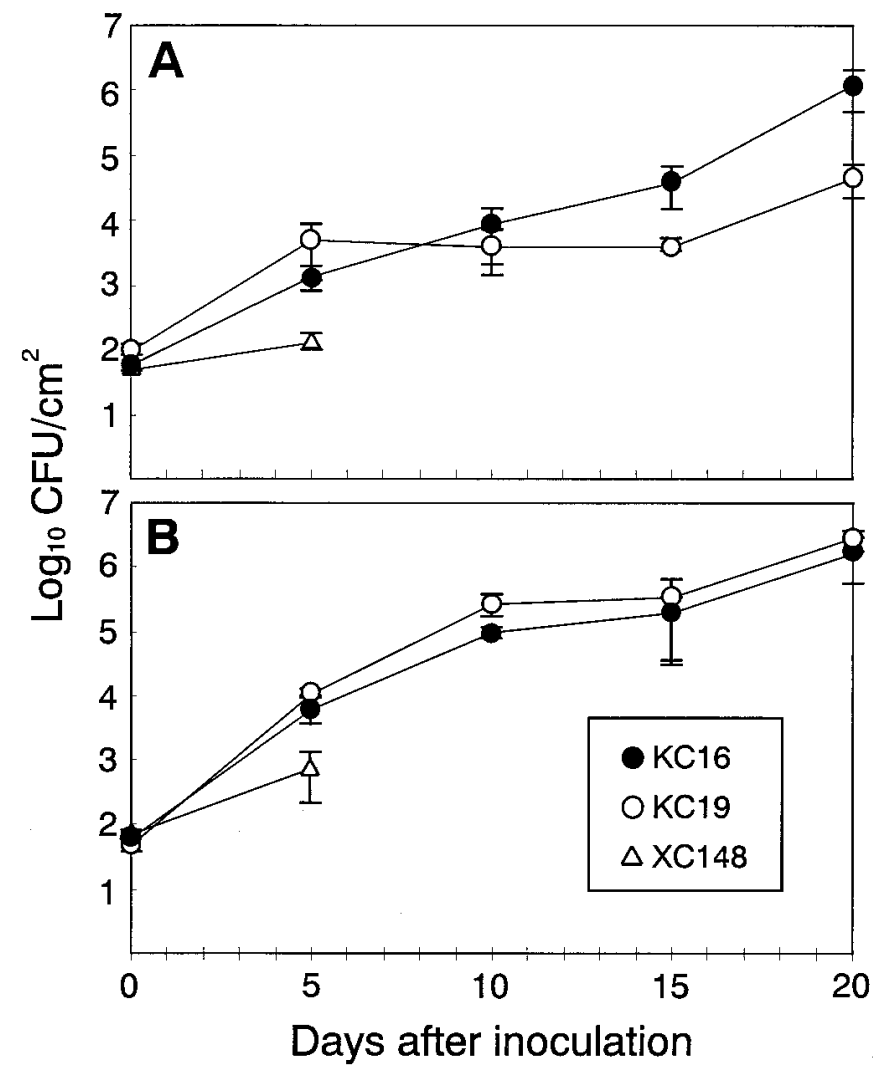

Fig. 5. Time course of bacterial growth in leaves of citrus species $\mathbf{A}$, pummelo 'Otachibana' and B, navel orange. An aggressive strain Xanthomonas axonopodis pv. citri $\mathrm{KC} 16$, a weakly aggressive strain $\mathrm{KC} 19$, and $X$. axonopodis pv. aurantifolli $\mathrm{XC} 148$ were inoculated into citrus leaves by infiltration at a concentration of $1 \times 10^{5}$ cells per ml. Leaves were sampled for 20 days after inoculation. Values are means from three repetitions, and vertical bars represent the standard error at each sampling time. 
sensitive to $\mathrm{Cp} 2$ and resistant to $\mathrm{Cp} 1$, however, were aggressive. Strain KC12, which was resistant to both phages, was also aggressive on 'Otachibana' (Table 1). Thus, resistance to Cp1 may indicate aggressive pathogenicity on 'Otachibana'. Strains sensitive to both phages, however, included both aggressive and weakly aggressive strains (NCPPB409, KC2, and KC20 in the aggressive group and $\mathrm{KC} 3, \mathrm{KC} 33$, and $\mathrm{KC} 34$ in the weakly aggressive group) (Table 1).

Genotypic variation between groups of $X$. axonopodis pv. citri by rep-PCR. DNA fingerprints were generated from the total DNA extracted from 42 strains of $X$. axonopodis pv. citri (Table 1). Using primers corresponding to the ERIC sequences, PCR resulted in complex fingerprinting patterns consisting of 15 to $16 \mathrm{PCR}$ products ranging in size from approximately 0.2 to $2.5 \mathrm{~kb}$ (Fig. 6; data not shown). Although the fingerprinting patterns were similar, they could be classified into two distinct genotypes based on the amplification of a 1.8-kb fragment by PCR (Fig. 6). This 1.8-kb PCR product was amplified only when the total DNA of the strains in the aggressive group was used as the template (Fig. 6). DNA fingerprints generated from the total DNA extracted from reference strain XC148 of $X$. axonopodis pv. aurantifolli were distinct from those of $X$. axonopodis pv. citri (Fig. 6).

\section{DISCUSSION}

Differential aggressiveness among $X$. axonopodis pv. citri strains was observed on $C$. grandis ('Otachibana'), based on analyses of bacterial growth in planta as well as lesion expansion after prick inoculation. The growth of an aggressive and a weakly

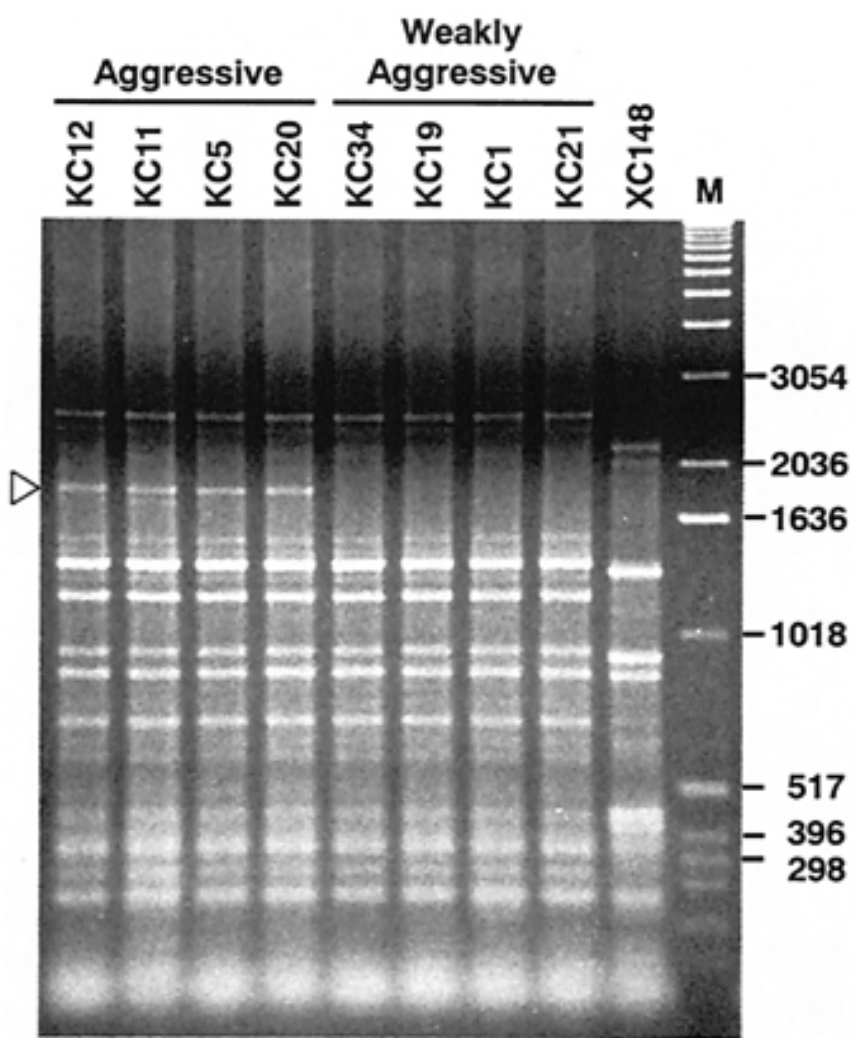

Fig. 6. Agarose gel electrophoresis of repetitive sequence-based polymerase chain reaction (rep-PCR). Fingerprinting patterns obtained using bacterial genomic DNA and primers enterobacterial repetitive intergeneric consensus (ERIC)1R and ERIC2. Fingerprints of aggressive strains (KC12, KC11, KC5, and $\mathrm{KC} 20$ ) and of weakly aggressive strains (KC34, $\mathrm{KC} 19, \mathrm{KC} 1$, and $\mathrm{KC} 21$ ) of Xanthomonas axonopodis pv. citri are shown. A reference fingerprint of a $X$. axonopodis pv. aurantifolli strain $(\mathrm{XC148)}$ is also shown. Lane $\mathrm{M}$ contains DNA size markers; sizes are indicated in base pairs. The arrowhead indicates the characteristic $1.8-\mathrm{kb}$ PCR product that was found only in the aggressive strains. aggressive strain differed after inoculation by infiltration. Populations of both strains in 'Otachibana' continued to increase 10 days after inoculation by infiltration. Egel et al. (3) reported that infiltrating into the leaf mesophyll might be a means of delivering bacteria to many susceptible sites over a large area. These findings are in contrast to the observed decrease 8 days after inoculation by pricking. Bacteria inoculated by infiltration may have more room in the host to increase in number, compared with those inoculated by pricking.

'Otachibana' has been classified as an independent species, $C$. otachibana, by Tanaka (25). Nevertheless, this plant, grown in Japan, is distinct morphologically from that described by Tanaka. It is, however, identical with 'Tosa-buntan' of $C$. grandis $(10,29)$. $C$. grandis has been distinguished from other members of the genus by numerical and biochemical analyses $(2,11,20)$. The possible inclusion of 'Otachibana', 'Banpeiyu', and 'Anseikan' in the species $C$. grandis may imply that the differential aggressiveness observed is characteristic of the relationship between $X$. axonopodis pv. citri and this species.

Avirulence (avr)/pathogenicity ( $p t h)$ genes have been identified in bacterial pathogens such as Xanthomonas spp. (4). X. axonopodis pv. citri has pth genes, belonging to the avrBs 3 family that are required for eliciting canker symptoms $(4,13,24)$, but no avr genes that elicit a resistant reaction in any Citrus spp. have been reported. The existence of $p t h$ genes in X. axonopodis pv. citri might suggest their involvement in the specific interaction between pummelo cultivars and the pathogen. A weakly aggressive strain of $X$. axonopodis pv. citri inoculated into 'Otachibana' by infiltrating at high cell densities, however, did not elicit rapid necrosis corresponding to a hypersensitive reaction; instead, it produced canker symptoms that were identical to those produced by an aggressive strain. This result indicates that an $a v r$ gene may not be involved in the specific interaction observed in the present study. Instead, positive host range determinants such as the $h s v$ genes for host-specific virulence that have been identified in $X$. campestris pv. translucens (31), may affect the specific interaction between pummelos and X. axonopodis pv. citri.

Aggressiveness of $X$. axonopodis pv. aurantifolli has been reported to be significantly less than that of strains from $X$. $a x$ onopodis pv. citri on several Citus spp. (7). The reference strain of this bacterium used in our study also showed less bacterial growth in 'Otachibana' and navel orange than either an aggressive or a weakly aggressive strain of $X$. axonopodis pv. citri.

Differential aggressiveness in $X$. axonopodis pv. citri appears to be correlated with phage sensitivity. One of the mechanisms involved in phage sensitivity may be related to the differential aggressiveness. Nevertheless, the few exceptions that were observed with some of the strains suggests this might not be true. Differences in phage sensitivity appear to be correlated with the bacteria's ability to oxidize mannitol (6). Specifically, the strains sensitive to phage $\mathrm{Cp} 1$ oxidize and use mannitol as a sole carbohydrate source. This correlation was also observed in the present study (data not shown). These observations could be useful in ecological studies of the pathogen.

Phenotypically distinct strains of $X$. axonopodis pv. citri have been isolated in Southwest Asia (28). They were resistant to Cp1 and Cp2 phages (28). In contrast, most Japanese strains are sensitive to the phages, indicating that the Japanese strains are different from the Southwest Asian strains (17). In addition, the Southwest Asian strains elicit no or limited water-soaking on detached grapefruit leaves (28). Water-soaking and an erumpent tissue reaction, however, have been observed on this plant for all Japanese strains of the pathogen (data not shown). Therefore, the Japanese strains used in this study appear to be the causal agent of Asiatic citrus canker.

Rep-PCR with ERIC primers showed that the two groups (aggressive and weakly aggressive), without exception, can be identified based on the presence or absence of a $1.8-\mathrm{kb}$ fragment. 
Amplified DNA fragments other than the 1.8-kb fragment were identical between the two groups. In addition, rep-PCR analysis with REP sequences (16) as the primer set also showed an identical fingerprint profile, without exception, among the strains in the two groups (data not shown). These results are consistent with observations in previous studies of genetic uniformity among $X$. axonopodis pv. citri strains $(5,9,23)$. Therefore, the differential aggressiveness within $X$. axonopodis pv. citri might be associated with limited genomic variation (16). The ERIC sequences appear to be restricted to transcribed sequences of neighboring genes in Escherichia coli and Salmonella typhimurium (12). Although we have found no evidence that the 1.8-kb fragment carries a gene that is required for the specific interaction between pummelo cultivars and $X$. axonopodis pv. citri, investigating the sequences might contribute to a better understanding of the genetic mechanism of the interaction.

\section{ACKNOWLEDGMENTS}

This work was supported in part by a grant-in-aid for special scientific research on agriculture, forestry, and fisheries from the Ministry of Agriculture, Forestry, and Fisheries of Japan. We thank J. S. Hartung for providing the XC148 strain of $X$. axonopodis pv. aurantifolli, and the citrus growers and researchers for their cooperation in collecting Japanese strains of $X$. axonopodis pv. citri.

\section{LITERATURE CITED}

1. Ausubel, F. M., Brent, R., Kingston, R. E., Moore, D. D., Seidman, J. G., Smith, J. A., and Struhl, K. 1995. Current Protocols in Molecular Biology. John Wiley \& Sons, New York.

2. Barrett, H. C., and Rhodes, A. M. 1976. A numerical taxonomic study of affinity relationships in cultivated Citrus and its close relatives. Syst. Bot. 1:105-136.

3. Egel, D. S., Graham, J. H., and Riley, T. D. 1991. Population dynamics of strains of Xanthomonas campestris differing in aggressiveness on Swingle citrumelo and grapefruit. Phytopathology 81:666-671.

4. Gabriel, D. W. 1999. The Xanthomonas avr/pth gene family. Pages 3955 in: Plant-Microbe Interactions. Vol. 4. G. Stacey and N. T. Keen, eds. The American Phytopathological Society, St. Paul, MN.

5. Gabriel, D. W., Hunter, J. E., Kingsley, M. T., Miller, J. W., and Lazo, G. R. 1988. Clonal population structure of Xanthomonas campestris and genetic diversity among citrus canker strains. Mol. Plant-Microbe Interact. 1:59-65.

6. Goto, M. 1962. Studies on citrus canker I. In Japanese. Bull. Fac. Agric. Shizuoka Univ. 12:3-72 (summary in English).

7. Goto, M., Takahashi, T., and Messina, M. A. 1980. A comparative study of the strains of Xanthomonas campestris pv. citri isolated from citrus canker in Japan and cancrosis B in Argentina. Ann. Phytopathol. Soc. Jpn. 46:329-338

8. Graham, J. H., and Gottwald, T. R. 1990. Variation in aggressiveness of Xanthomonas campestris pv. citrumelo associated with citrus bacterial spot in Florida citrus nurseries. Phytopathology 80:190-196.

9. Hartung, J. S., and Civerolo, E. L. 1989. Restriction fragment length polymorphisms distinguish Xanthomonas campestris strains isolated from Florida citrus nurseries from X. c. pv. citri. Phytopathology 79:793799.

10. Hashimoto, H. 1976. On the special diagnosis and the history of Tosabuntan (Citrus grandis Osbeck forma Tosa-buntan). In Japanese. Bull. Kochi Fruit Tree Exp. Stn. Jpn. 1:1-10 (summary in English).

11. Hirai, M., and Kajiura, I. 1987. Genetic analysis of leaf isozyme in cit- rus. Jpn. J. Breed. 37:377-388.

12. Hulton, C. S. J., Higgins, C. F., and Sharp, P. M. 1991. ERIC sequences: A novel family of repetitive elements in the genomes of Escherichia coli, Salmonella typhimurium and other enterobacteria. Mol. Microbiol. 5:825-834

13. Kanamori, H., and Tsuyumu, S. 1998. Comparison of nucleotide sequences of canker-forming and non-canker-forming pthA homologues in Xanthomonas campestris pv. citri. Ann. Phytopathol. Soc. Jpn. 64:462470.

14. Kogan, S. C., Doherty, M., and Gitschier, J. 1987. An improved method for prenatal diagnosis of genetic diseases by analysis of amplified DNA sequences. New Eng. J. Med. 317:985-990.

15. Koizumi, M., and Kuhara, S. 1982. Evaluation of citrus plants for resistance to bacterial canker disease in relation to the lesion extension. Bull. Fruit Tree Res. Stn. D 4:73-92.

16. Louws, F. J., Fulbright, D. W., Stephens, C. T., and de Bruijn, F. J. 1994. Specific genomic fingerprints of phytopathogenic Xanthomonas and Pseudomonas pathovars and strains generated with repetitive sequences and PCR. Appl. Environ. Microbiol. 60:2286-2295.

17. Obata, T. 1974. Distribution of Xanthomonas citri strain in relation to the sensitivity to phages $\mathrm{CP}_{1}$ and $\mathrm{CP}_{2}$. Ann. Phytopathol. Soc. Jpn. 40:613 .

18. Ozaki, K., and Shiotani, H. 1999. Selective medium for isolation of Xanthomonas campestris pv. Citri. In Japanese. (Abstr.). Ann. Phytopathol. Soc. Jpn. 65:362.

19. Permar, T. A., and Gottwald, T. R. 1989. Specific recognition of a Xanthomonas campestris Florida citrus nursery strain by a monoclonal antibody probe in a microfiltration enzyme immunoassay. Phytopathology 79:780-783.

20. Potvin, C., Bergeron, Y., and Simon, J. P. 1983. A numerical taxonomic study of selected Citrus species (Rutaceae) based on biochemical characters. Syst. Bot. 8:127-133.

21. Sambrook, J., Fritsch, E. F., and Maniatis, T. 1989. Molecular Cloning: A Laboratory Manual. 2nd ed. Cold Spring Harbor Laboratory, Cold Spring Harbor, NY.

22. Stall, R. E. 1988. Canker. Pages 6-7 in: Compendium of Citrus Diseases. J. O. Whiteside, S. M. Garnsey, and L. W. Timmer, eds. The American Phytopathological Society, St. Paul, MN.

23. Stall, R. E., and Civerolo, E. L. 1991. Research relating to the recent outbreak of citrus canker in Florida. Annu. Rev. Phytopathol. 29:399420 .

24. Swarup, S., Yang, Y., Kingsley, M. T., and Gabriel, D. W. 1992. An Xanthomonas citri pathogenicity gene, pthA, pleiotropically encodes gratuitous avirulence on nonhosts. Mol. Plant-Microbe Interact. 5:204-213.

25. Tanaka, T. 1977. Fundamental discussion of citrus classification Stud Citrogica 14:1-6.

26. Varsalovic, J., Koeuth, T., and Lupski, J. R. 1991. Distribution of repetitive DNA sequences in eubacteria and application of fingerprinting of bacterial genomes. Nucleic Acids Res. 19:6823-6831.

27. Vauterin, L., Hoste, B., Kersters, K., and Swings, J. 1995. Reclassification of Xanthomonas. Int. J. Syst. Bacteriol. 45:472-489.

28. Vernière, C., Hartung, J. S., Pruvost, O. P., Civerolo, E. L., Alvarez, A. M., Maestri, P., and Luisetti, J. 1998. Characterization of phenotypically distinct strains of Xanthomonas axonopodis pv. citri from Southwest Asia. Eur. J. Plant Pathol. 104:477-487.

29. Wakana, A., Ngo, X. B., Hanada, N., and Fukudome, I. 1998. Diversity of GOT isozymes of old pomelo trees found in Kyushu area. (Abstr.) Mem. Jpn. Soc. Hortic. Sci., Kyushu Branch 6:1-2 (in Japanese).

30. Wakimoto, S. 1967. Some characteristics of citrus canker bacteria, Xanthomonas citri (Hasse) Dowson, and the related phages isolated from Japan. Ann. Phytopathol. Soc. Jpn. 33:301-310.

31. Warney, V. R., Kingsley, M. T., and Gabriel, D. W. 1991. Xanthomonas campestris pv. translucens genes determining host-specific virulence and general virulence on cereals identified by Tn5-gusA insertion mutagenesis. Mol. Plant-Microbe Interact. 4:623-627. 